www.mdpi.com/journal/marinedrugs

Article

\title{
Antioxidant and Antimicrobial Potential of the Bifurcaria bifurcata Epiphytic Bacteria
}

\section{André Horta ${ }^{1, \dagger}$, Susete Pinteus ${ }^{1, \dagger}$, Celso Alves ${ }^{1}$, Nádia Fino ${ }^{1}$, Joana Silva ${ }^{1}$, Sara Fernandez ${ }^{2}$, Américo Rodrigues ${ }^{1,3}$ and Rui Pedrosa ${ }^{1,4, *}$}

1 Marine Resources Research Group (GIRM), School of Tourism and Maritime Technology (ESTM), Polytechnic Institute of Leiria, 2520-641 Peniche, Portugal; E-Mails: andre.horta@ipleiria.pt (A.H.); susete.pinteus@ipleiria.pt (S.P.); celso.alves@ipleiria.pt (C.A.); nadia.fino@ipleiria.pt (N.F.); joana.m.silva@ipleiria.pt (J.S.); arodrigues@ipleiria.pt (A.R.)

2 Higher School of Agricultural Engineering (ETSEA), University of Lleida, E-25003 Lleida, Spain; E-Mail: sara_lofer@hotmail.com

3 Gulbenkian Institute of Science, 2780-156 Oeira, Portugal

4 Center of Pharmacology and Chemical Biopathology, Faculty of Medicine, University of Porto, 4200-319 Porto, Portugal

$\dagger$ These authors contributed equally to this work.

* Author to whom correspondence should be addressed; E-Mail: rpedrosa@ipleiria.pt; Tel.: +35-1-262-783-325; Fax: +35-1-262-783-088.

Received: 31 December 2013; in revised form: 14 January 2014 / Accepted: 4 March 2014 / Published: 24 March 2014

\begin{abstract}
Surface-associated marine bacteria are an interesting source of new secondary metabolites. The aim of this study was the isolation and identification of epiphytic bacteria from the marine brown alga, Bifurcaria bifurcata, and the evaluation of the antioxidant and antimicrobial activity of bacteria extracts. The identification of epiphytic bacteria was determined by 16S rRNA gene sequencing. Bacteria extracts were obtained with methanol and dichloromethane (1:1) extraction. The antioxidant activity of extracts was performed by quantification of total phenolic content (TPC), 2,2-diphenyl-1-picrylhydrazyl (DPPH) radical scavenging activity and oxygen radical absorbance capacity (ORAC). Antimicrobial activities were evaluated against Escherichia coli, Pseudomonas aeruginosa, Bacillus subtilis, Salmonella enteritidis, Staphylococcus aureus, Saccharomyces cerevisiae and Candida albicans. A total of 39 Bifurcaria bifurcata-associated bacteria were isolated and 33 were identified as Vibrio sp. (48.72\%), Alteromonas sp. (12.82\%), Shewanella sp. (12.26\%), Serratia sp. (2.56\%), Citricoccus sp. (2.56\%), Cellulophaga sp. (2.56\%),
\end{abstract}


Ruegeria sp. (2.56\%) and Staphylococcus sp. (2.56\%). Six (15.38\%) of the 39 bacteria Bifurcaria bifurcata-associated bacteria presented less than a 90\% Basic Local Alignment Search Tool (BLAST) match, and some of those could be new. The highest antioxidant activity and antimicrobial activity (against B. subtilis) was exhibited by strain 16 (Shewanella sp.). Several strains also presented high antimicrobial activity against S. aureus, mainly belonging to Alteromonas sp. and Vibrio sp. There were no positive results against fungi and Gram-negative bacteria. Bifurcaria bifurcata epiphytic bacteria were revealed to be excellent sources of natural antioxidant and antimicrobial compounds.

Keywords: marine microorganisms; natural compounds; human pathogenic; Alteromonas sp.; Shewanella sp.; antibacterial; surface-associated microorganisms; marine symbiosis; macro-algae; seaweeds

\section{Introduction}

The marine environment is extremely complex and contains a huge diversity of life forms, which is a huge source of biological and chemical diversity [1-3]. The complex interactions between biological and chemical factors stimulate marine organisms to produce a high spectrum of different compounds with biological activities [4,5]. Among other reasons, marine organisms produce these compounds as a response to ecological pressures, since they survive and live within complex communities and in close association with other organisms in a very exigent, competitive and aggressive surrounding $[4,6]$. Sharing a common environment over a long evolutionary period also allowed the establishment of well-balanced associations between many of these organisms [7]. The surfaces of marine eukaryotes provide a unique habitat for microorganisms colonization, where competition between members of these communities and chemically-mediated interactions with their host are thought to influence both microbial diversity and function [8]. This close association of marine eukaryotes with microorganisms improves their physiological capacities, mainly providing microbial defenses [9]. For sessile marine organisms, like macro-algae, this association is an important strategy of survival in the environment where they live, since it is known that marine microorganisms strengthen the host defense mechanism by producing various kinds of secondary metabolites. Many of these metabolites have been recognized to be rich in chemical and biological properties $[10,11]$. Studies focusing on symbiotic relationships in marine environment indicate that many bioactive compounds previously found in marine animals and plants were in fact produced or metabolized by associated microorganisms [12-14]. For these reasons, in recent years, microorganisms associated with the surfaces of marine eukaryotes have been major targets for the discovery of new bioactive metabolites [15].

Among marine organisms, macro-algae can host varieties of heterotrophic bacteria, and many of these bacteria play an important role in maintaining the health of the host organism by producing unique bioactive secondary metabolites. With the increasing need for novel drug discovery, an understanding of the marine epiphyte-host associations outlined above is likely to deliver a rich source of preexisting and of new high value-added biomolecules with the potential for providing sustainable economic and human benefits $[8,9,16,17]$. These bioactive compounds with biomedical potential can 
have an important role in the prevention or treatment of human diseases, like infectious diseases and diseases associated with oxidative damage that have a high impact in world society.

Bifurcaria bifurcata is a perennial brown alga, found abundantly along the North East Atlantic shores, from Ireland as the northern limit, to south of the Western Sahara as the southern limit [18]. Previous studies reported a high antioxidant and antimicrobial potential in Bifurcaria bifurcata extracts $[19,20]$. However, little is known about the biodiversity of its associated bacteria and their capacity in the production of bioactive compounds. Therefore, the aim of this study was the isolation and identification of epiphytic bacteria from Bifurcaria bifurcata and the evaluation of the antioxidant and antimicrobial activities of extracts obtained from the isolated strains.

\section{Results and Discussion}

The oceans are massively complex and consist of diverse assemblages of life forms. The water column of the oceans contains approximately $10^{6}$ bacterial cells per milliliter [21]. In this study, 39 phenotypic different bacteria from the Bifurcaria bifurcata surface were isolated, and the strains were subjected to molecular identification using 16S rRNA gene sequencing.

As shown in Table 1, Vibrio sp. was the most common bacteria, representing $48.72 \%$ of all the B. bifurcata isolated bacteria. Bacteria belonging to the Vibrionaceae family are widespread in the marine environment. This family is particularly abundant on the surface of marine macroorganisms, where they form commensal, symbiotic or pathogenic associations [22]. Alteromonas sp. and Shewanella sp. were the following more representative genus, with $12.82 \%$ and $12.26 \%$ of occurrence, respectively. Both strains are frequent in the marine environment and have already been found to be associated with marine invertebrates, namely sponges and algae [23,24]. Cellulophaga sp., Serratia sp., Ruegeria sp., Staphylococcus sp. and Citricoccus sp. were represented by one strain each $(2.56 \%)$. However, these bacteria are found to be frequently associated with marine invertebrates and have been the focus of study by other authors [11,25-28].

Table 1. The identification of epiphytic bacteria isolated from Bifurcaria bifurcata, at the genus level. BLAST, Basic Local Alignment Search Tool.

\begin{tabular}{ccc}
\hline Epiphytic Bacteria & Genus & Occurrence (\%) \\
\hline 1 & Citricoccus $\mathrm{sp}$. & 2.56 \\
$2 ; 3 ; 10 ; 11 ; 13 ; 14 ; 15 ; 18 ; 20 ; 21 ;$ & Vibrio $\mathrm{sp}$. & 48.72 \\
$22 ; 23 ; 29 ; 31 ; 35 ; 39 ; 40 ; 50 ; 51$ & Cellulophaga sp. & 2.56 \\
4 & Alteromonas $\mathrm{sp}$. & 12.82 \\
$6 ; 12 ; 28 ; 30 ; 34$ & Serratia $\mathrm{sp}$. & 2.56 \\
$13 \mathrm{~B}$ & Shewanella $\mathrm{sp}$. & 12.26 \\
$16 ; 17 ; 25 ; 26$ & Ruegeria $\mathrm{sp}$. & 2.56 \\
27 & Staphylococcus $\mathrm{sp}$. & 2.56 \\
32 & $<90 \%$ BLAST match & 15.38 \\
\hline
\end{tabular}

Marine bacteria develop unique metabolic and physiological capabilities, which enable them to survive in extreme habitats and to produce compounds that might not be produced by their terrestrial counterparts $[1,6]$. 
In this work, marine bacteria were isolated from the brown alga, Bifurcaria bifurcata, and screened for their antioxidant and antimicrobial capacities. Since there is not a specific method to evaluate the antioxidant activity of a compound/extract, due to different antioxidant mechanisms, the antioxidant activity was evaluated through three methods, namely, oxygen radical absorbance capacity (ORAC), 2,2-diphenyl-1-picrylhydrazyl (DPPH) radical scavenging activity and total phenolic content (TPC).

The antioxidant results are stated in Table 2. The TPC was evaluated by the Folin-Ciocalteu method, and the results are expressed as gallic acid equivalents per gram of extract (GAE/g extract). Bacteria 16, belonging to the Shewanella genus, showed the highest phenolic content $(53.854 \pm 3.02 \mathrm{GAE} / \mathrm{g}$ extract) followed by Bacteria $8(14.222 \pm 4.25 \mathrm{GAE} / \mathrm{g}$ extract) and 36 $(10.376 \pm 1.58 \mathrm{GAE} / \mathrm{g}$ extract). There are not many works quantifying the total phenolic content of marine bacteria, especially epiphytic algae. However, a total phenolic content of $0.22 \mathrm{mg} \mathrm{GAE} / \mathrm{g}$ of extract was found on the marine Actinobacteria, which was significantly lower when compared with the results obtained by the B. bifurcata-associated bacteria study [29]. Moreover, the phenolic content found on Bacteria 16 was surprisingly high, even when compared with the total phenolic content of some macro-algae [30].

Table 2. Antioxidant activity of Bifurcaria bifurcata epiphytic bacteria. The results are the mean \pm SEM of four independent experiments. TPC, total phenolic content; GAE, gallic acid equivalents; DPPH, 2,2-diphenyl-1-picrylhydrazyl; ORAC, oxygen radical absorbance capacity; TE, trolox equivalents; BHT, butylated hydroxytoluene.

\begin{tabular}{cccc}
\hline $\begin{array}{c}\text { Epiphytic } \\
\text { Bacteria }\end{array}$ & $\begin{array}{c}\text { TPC } \\
(\mathbf{m g} \text { GAE/g Extract) }\end{array}$ & $\begin{array}{c}\text { DPPH Radical Scavenging } \\
\text { Activity } \mathbf{I C}_{\mathbf{5 0}}(\boldsymbol{\mu g} \mathbf{m L})\end{array}$ & $\begin{array}{c}\text { ORAC } \\
(\boldsymbol{\mu m o l ~ T E} / \mathbf{g ~ E x t r a c t})\end{array}$ \\
\hline 1 & $3.040 \pm 0.32$ & $>1000$ & $417.245 \pm 9.44$ \\
2 & $7.120 \pm 0.05$ & $>1000$ & $43.220 \pm 6.41$ \\
3 & $2.080 \pm 0.19$ & $>1000$ & $254.218 \pm 6.47$ \\
4 & $1.352 \pm 0.09$ & $>1000$ & $154.985 \pm 3.04$ \\
6 & $2.923 \pm 0.05$ & $>1000$ & $242.595 \pm 6.68$ \\
8 & $14.222 \pm 4.25$ & $164.40(109.40-247.10)$ & $912.621 \pm 23.79$ \\
9 & $4.870 \pm 0.02$ & $>1000$ & $34.420 \pm 1.63$ \\
10 & $6.090 \pm 0.07$ & $>1000$ & $20.400 \pm 4.99$ \\
11 & $6.530 \pm 0.05$ & $183.80(118.50-285.20)$ & $31.220 \pm 2.06$ \\
12 & $2.540 \pm 0.30$ & $>1000$ & $215.289 \pm 7.46$ \\
13 & $9.750 \pm 0.04$ & $>1000$ & $33.950 \pm 4.40$ \\
14 & $5.990 \pm 0.06$ & $>1000$ & $47.950 \pm 5.77$ \\
15 & $5.390 \pm 0.07$ & $>1000$ & $29.370 \pm 2.62$ \\
16 & $53.854 \pm 3.02$ & $20.21(14.41-28.34)$ & $3603.659 \pm 53.38$ \\
17 & $6.470 \pm 0.09$ & $>1000$ & $44.250 \pm 2.28$ \\
18 & $1.633 \pm 0.19$ & $>1000$ & $202.810 \pm 4.75$ \\
20 & $7.140 \pm 0.01$ & $>1000$ & $52.110 \pm 8.20$ \\
21 & $1.668 \pm 0.06$ & $>1000$ & $131.556 \pm 2.36$ \\
22 & $0.878 \pm 0.06$ & $>1000$ & $119.415 \pm 3.05$ \\
23 & $2.035 \pm 0.15$ & $>1000$ & $561.990 \pm 12.69$ \\
24 & $3.220 \pm 0.25$ & $>1000$ & $407.490 \pm 5.39$ \\
25 & $9.380 \pm 0.06$ & $>1000$ & $42.720 \pm 4.08$ \\
\hline & & &
\end{tabular}


Table 2. Cont.

\begin{tabular}{cccc}
\hline 26 & $5.656 \pm 0.13$ & $521.00(366.90-739.70)$ & $520.917 \pm 14.13$ \\
27 & $2.640 \pm 0.01$ & $>1000$ & $12.210 \pm 0.68$ \\
28 & $1.848 \pm 0.21$ & $>1000$ & $149.545 \pm 5.53$ \\
29 & $1.117 \pm 0.13$ & $>1000$ & $67.211 \pm 0.99$ \\
30 & $3.502 \pm 0.12$ & $>1000$ & $68.979 \pm 0.93$ \\
31 & $8.556 \pm 1.89$ & $>1000$ & $692.260 \pm 13.61$ \\
32 & $1.963 \pm 0.21$ & $>1000$ & $201.190 \pm 4.99$ \\
34 & $2.220 \pm 0.16$ & $>1000$ & $204.646 \pm 1.89$ \\
35 & $2.770 \pm 0.04$ & $>1000$ & $358.226 \pm 14.32$ \\
36 & $10.376 \pm 1.58$ & $587.70(442.00-781.40)$ & $129.665 \pm 0.91$ \\
38 & $5.340 \pm 0.07$ & $>1,000$ & $55.290 \pm 3.11$ \\
39 & $7.150 \pm 0.03$ & $23.62(19.45-28.68)$ & $36.100 \pm 4.69$ \\
40 & $5.900 \pm 0.02$ & $>1000$ & $71.000 \pm 15.49$ \\
44 & $3.772 \pm 0.44$ & $>1000$ & $97.450 \pm 2.11$ \\
50 & $4.106 \pm 0.02$ & $>1000$ & $33.120 \pm 0.42$ \\
51 & $1.586 \pm 0.89$ & $>1000$ & $246.910 \pm 9.97$ \\
$13 \mathrm{~B}$ & $4.270 \pm 0.02$ & $>1000$ & $18.880 \pm 0.24$ \\
BHT & - & $40.55(27.39-60.05)$ & - \\
\hline
\end{tabular}

Regarding the DPPH radical scavenging activity, the highest potency was produced by Bacteria 16 (Shewanella sp.) and Bacteria 39 (Vibrio sp.), which showed an $\mathrm{IC}_{50}$ of $20.21(14.41-28.34) \mu \mathrm{g} / \mathrm{mL}$ and $23.6(19.5-28.7) \mu \mathrm{g} / \mathrm{mL}$, respectively. The Bacteria 8, 11, 26 and 36 also denoted quite high antioxidant activity on the reduction of $\mathrm{DPPH}$ with an $\mathrm{IC}_{50}$ of $164(109-247) \mu \mathrm{g} / \mathrm{mL}, 183.8$ (118.5-285.2) $\mu \mathrm{g} / \mathrm{mL}, 521(366.9-739.7) \mu \mathrm{g} / \mathrm{mL}$ and 587.7 (442-781.4) $\mu \mathrm{g} / \mathrm{mL}$, respectively. These results are extremely interesting, especially when compared with the synthetic antioxidant, BHT (butylated hydroxytoluene), which presented an $\mathrm{IC}_{50}$ of $40.55(27.39-60.05) \mu \mathrm{g} / \mathrm{mL}$, since Bacteria 16 and 39 presented more potency in scavenging the DPPH radical. Kalirajan and co-workers [31] evaluated the DPPH radical scavenging activity of bacteria associated with a marine sponge and obtained an $\mathrm{IC}_{50}$ of $857.49 \mu \mathrm{g} / \mathrm{mL}$, which is 40 times less potent than that obtained for Bacteria 16 and 39 in our work.

Recently, the ORAC assay has received much attention as a new in vitro method for measuring the antioxidant activity of marine extracts by evaluating their ability to scavenge certain peroxyl-radicals that induce oxidation in the presence of fluorescein [32]. According to Zulueta and co-workers [33], the ORAC method is the only one so far that combines the total inhibition time and the percentage of the free-radical damage by the antioxidant into a single quantity, ensuring that, by the end of the process, all the antioxidants present in the sample have reacted with the radicals generated. Further evaluation of the peroxyl scavenging activity of the B. bifurcata epiphytic bacteria extracts was also conducted by ORAC assay, and the results were expressed as trolox equivalents per gram of extract (TE/g extract). Once more, Bacteria 16 showed the highest antioxidant activity with an ORAC value of $3603.659 \pm 53.38 \mu \mathrm{mol}$ of TE/g extract, followed by Bacteria 8, 31, 23 and 26 with $912.621 \pm 23.79 \mu \mathrm{mol}$ of TE/g extract, $692.260 \pm 13.61 \mu \mathrm{mol}$ of TE/g extract, $561.990 \pm 12.69 \mu \mathrm{mol}$ of TE/g extract and $520.917 \pm 14.13 \mu \mathrm{mol}$ of $\mathrm{TE} / \mathrm{g}$ extract, respectively. The lack of information about the production of antioxidant compounds produced by marine epiphytic bacteria, namely evaluated by the ORAC 
method, does not allow us to make a direct comparison with other works; however, Wang and co-workers [34] evaluated the peroxyl radical scavenging activity also by the ORAC system in 10 macro-algae species from Iceland, and they obtained values ranging from 4 to $2567 \mu \mathrm{mol}$ of TE/g extract, which are values substantially lower than the results obtained by our bacteria extracts, since the lowest result was $12.210 \pm 0.68 \mu \mathrm{mol}$ of $\mathrm{TE} / \mathrm{g}$ of extract (Bacteria 27) and the highest was $3603.659 \pm 53.38 \mu \mathrm{mol}$ of TE/g of extract (Bacteria 16).

The high antioxidant activity of B. bifurcata epiphytic bacteria presented in this work can be explained by the environmental conditions where these bacteria exist. They live in close association with soft-bodied marine organisms, which lack obvious structural defense mechanisms, and, thus, rely on chemical defense by the production of bioactive secondary metabolites to survive in their extreme habitat [1]. The production of ROS is prevalent in the world's oceans, and oxidative stress is an important component of the stress response in marine organisms. In marine systems, the absorption of solar radiation by dissolved organic matter in seawater leads to the photochemical production of diverse reactive transients, including ROS. Since marine organisms cannot avoid these challenges, they produce compounds that can operate as antioxidant defenses [35].

It is well known that the genus, Shewanella (Bacteria 16), produces long-chain polyunsaturated fatty acids, and recent studies associated these compounds with an efficient antioxidant system mechanism, which operates as a primary protective "breakwater" for all marine microorganisms possessing them [35]. This can explain the high antioxidant activity shown by Bacteria 16 (Shewanella sp.).

Besides the production of antioxidant compounds, marine bacteria also have the ability to produce antimicrobial compounds that play an important role in the protection against other pathogenic and fouling microorganisms [22].

In this work, the antimicrobial activity of compounds produced by B. bifurcata epiphytic bacteria was also evaluated against several microorganisms, including human pathogens, namely Staphylococcus aureus, Escherichia coli, Pseudomonas aeruginosa, Candida albicans, Saccharomyces cerevisiae, Salmonella enteritidis and Bacillus subtilis. Extracts were tested against all the mentioned microorganisms at $1 \mathrm{mg} / \mathrm{mL}$; the ones that presented a capacity to inhibit the microorganism's growth in more than $50 \%\left(\mathrm{IC}_{50}<1 \mathrm{mg} / \mathrm{mL}\right)$ were also evaluated through dose-response analysis $(10,30,100$, 300 and $1000 \mu \mathrm{g} / \mathrm{mL}$ ), and the $\mathrm{IC}_{50}$ was determined. The B. bifurcata-associated bacteria extracts did not show antimicrobial activity against Escherichia coli, Pseudomonas aeruginosa, Candida albicans, Saccharomyces cerevisiae and Salmonella enteritidis (data not shown). However, several of the B. bifurcata-associated bacteria extracts induced high antibacterial activity against Bacillus subtilis and Staphylococcus aureus (Table 3). The obtained $\mathrm{IC}_{50}$ ranged from $2.29 \mu \mathrm{g} / \mathrm{mL}$ (1.79-2.94) to $621.4 \mu \mathrm{g} / \mathrm{mL}$ (508.2-759.9) exhibited by Bacteria 16 (Shewanella sp.) and 13 (Vibrio sp.), respectively, against B. subtilis, and $50.85 \mu \mathrm{g} / \mathrm{mL}(40.72-63.50)$ to $722.9 \mu \mathrm{g} / \mathrm{mL}(541.11-965.9)$ exhibited by Bacteria 34 (Alteromonas sp.) and 4 (Cellulophaga sp.), respectively, against $S$. aureus. Actually, the potency of some bacteria extracts against B. subtilis growth, such as Bacteria 16 (Shewanella sp.), 25 (Shewanella sp.), 17 (Shewanella sp.), 34 (Alteromonas sp.) and 24, was even higher than that of the commercial antibiotic, chloramphenicol. Moreover, the B. bifurcata-associated bacteria extracts from the Bacteria 13B (Serratia sp.), 39 (Vibrio sp.), 50 (Vibrio sp.) and 38 had a chloramphenicol similar potency. 
Table 3. Antibacterial activity of Bifurcaria bifurcata epiphytic bacteria. The results are the mean \pm SEM of eight independent experiments. Bacitracin, chloramphenicol, oxytetracycline and ampicillin were used as positive controls.

\begin{tabular}{|c|c|c|}
\hline Epiphytic bacteria & $\begin{array}{c}\text { B. subtilis } \\
\text { IC }_{50}(\mu \mathrm{g} / \mathrm{mL})\end{array}$ & $\begin{array}{c}\text { S. aureus } \\
\text { IC }_{50}(\mu \mathrm{g} / \mathrm{mL})\end{array}$ \\
\hline 2 & $95.06(82.41-109.7)$ & $>1000$ \\
\hline 3 & $122.4(87.66-170.9)$ & $95.54(67.26-135.7)$ \\
\hline 4 & $>1000$ & $722.9(541.11-965.9)$ \\
\hline 6 & $102.5(68.34-153.9)$ & $63.48(52.77-76.38)$ \\
\hline 9 & $532.3(452.2-626.6)$ & $>1000$ \\
\hline 13 & $621.4(508.2-759.9)$ & $>1000$ \\
\hline 14 & $148.5(115.9-190.4)$ & $>1000$ \\
\hline 15 & $126.4(91.68-174.2)$ & $>1000$ \\
\hline 16 & $2.29(1.79-2.94)$ & $>1000$ \\
\hline 17 & $36.97(29.97-45.60)$ & $>1000$ \\
\hline 18 & $98.32(84.47-114.4)$ & $>1000$ \\
\hline 23 & $739(525.5-1039)$ & $136.6(102.8-181.6)$ \\
\hline 24 & $47.39(30.12-74.58)$ & $>1000$ \\
\hline 25 & $31.01(21.49-44.75)$ & $>1000$ \\
\hline 30 & 71.35 (54.19-93.94) & $>1000$ \\
\hline 32 & $>1000$ & $127.1(85.79-188.4)$ \\
\hline 34 & $24.17(14.9-39.20)$ & $50.85(40.72-63.50)$ \\
\hline 35 & $303.3(144.5-636.5)$ & $>1000$ \\
\hline 38 & $58.87(41.39-83.74)$ & $>1000$ \\
\hline 39 & $58.86(43.60-79.46)$ & $>1000$ \\
\hline 40 & $411.5(323.8-522.9)$ & $>1000$ \\
\hline 50 & $62.54(39.57-98.86)$ & $>1000$ \\
\hline $13 \mathrm{~B}$ & $52.42(37.00-74.27)$ & $>1000$ \\
\hline Bacitracin & $4.09(3.30-5.06)$ & $4.05(3.35-4.90)$ \\
\hline Chloramphenicol & $48.14(33.73-68.71)$ & $26.01(19.06-35.5)$ \\
\hline Oxytetracycline & $0.16(0.128-0.19)$ & $0.40(0.265-0.610)$ \\
\hline Ampicillin & $0.16(0.124-0.21)$ & $0.04(0.028-0.05)$ \\
\hline
\end{tabular}

The extracts from Strains 34 and 6, which belong to the Alteromonas genus, showed the highest antimicrobial activity against Staphylococcus aureus with an $\mathrm{IC}_{50}$ of 50.85 and $43.48 \mu \mathrm{g} / \mathrm{mL}$, respectively. In line with our results, Barja and co-workers [36] isolated antimicrobial compounds from Alteromonas sp. that exhibited a broad inhibition, including against Staphylococcus aureus. Furthermore, Shiozawa and co-workers isolated a new antibiotic also produced by Alteromonas sp. with high antibacterial activity [37]. In another study, Alteromonas sp. isolated from a marine invertebrate also exhibited high antimicrobial activity, namely against fish pathogenic bacteria [38].

It is widely accepted that marine organisms produce compounds to survive and adapt to the unfavorable conditions where in which they live, and the production of antimicrobial compounds by marine bacteria seems to be a powerful weapon in space competition, namely for surfaces colonization. Other strains of Bacillus are current in the marine environment. For instance, Bacillus licheniformis (strain EI-34-6) and Bacillus subtilis (strain II-111-5) were isolated from the marine alga, 
Palmaria palmate [39]. Therefore, Bacillus strains are direct competitors of other species of marine epiphytic bacteria, like Shewanella sp., Alteromonas sp., Serratia sp. and Vibrio sp., which can explain the high antimicrobial activity of these bacteria's extracts against Bacillus subtilis. In line with these findings, it was not surprising that more than $50 \%$ of the total bacteria isolated from the $B$. bifurcata macro-alga presented antibacterial activity against $B$. subtilis.

According to the literature, the production of antimicrobial compounds by marine organisms against Gram-positive bacteria seems to be more frequent [1]. The generally low activity of compounds against Gram-negative organisms may be due to the fact that Gram-negative bacteria possess an outer membrane and a periplasmic space, both of which are absent in Gram-positive bacteria. The outer membrane of Gram-negative bacteria is known to present a barrier to the penetration of numerous antibiotic molecules. In addition, the periplasmic space contains enzymes that are capable of breaking down foreign molecules introduced from the outside [40]. Moreover, microbial competition for limited natural resources within a community is thought to be an important selective force that promotes the biosynthesis of antimicrobial compounds. From an ecological point of view, the inhibition of other marine bacterial species competing for the same niche will give a selective advantage during colonization [41]. In this study, the weak inhibitory effect against most bacteria and fungi can provide evidence of a lack of competition for the same niche.

In this study, some bacterial extracts revealed positive bioactivity results, and given that these are multi-component extracts, there is a potential for discovering multiple active compounds in a single fraction, making these organisms a valuable source of novel substances for future marine drug discovery. The very high antioxidant and antimicrobial activities observed could be associated with low-abundant substances, indicating a high potency for these compounds, especially for Bacteria 16 (Shewanella sp.), which revealed huge antioxidant and antimicrobial activities.

\section{Experimental Section}

\subsection{Isolation and Purification of Epiphytic Marine Bacteria}

Marine alga Bifurcaria bifurcata was collected from the Peniche coast and transported in seawater to the lab. Portions of alga were rinsed thoroughly with sterile seawater to remove loosely attached bacteria and then swabbed with a sterile cotton-tipped swab. The swab was then used to directly inoculate plates with Marine-Agar (peptone, $5 \mathrm{~g}$; yeast extract, $1 \mathrm{~g}$; $\mathrm{FePO}_{4}, 0.1 \mathrm{~g}$; agar, $15 \mathrm{~g}$; dissolved in $1 \mathrm{~L}$ of seawater; $\mathrm{pH} 7.2-7.6$ ), which were incubated at $20^{\circ} \mathrm{C}$. Colonies were selected at random and by systematic sampling, with distinctive colony types being selected along with a random sample from each plate. For purifying bacteria, we performed the streak technique at least 5 times.

\subsection{Bacterial DNA Extraction and Identification}

DNA was extracted from previously stored bacterial pellets with the GeneJETTM Genomic DNA Purification Kit (Thermo Fisher Scientific, Vilnius, Lithuania), according to the manufacturer's instructions. Genus-level identification of isolates was determined by $16 \mathrm{~S}$ rRNA gene sequencing. 16S rRNA gene fragments of $c a .1500 \mathrm{bp}$ in length were amplified using the bacterial universal primers, F27 (5'-AGA GTTTGATCMTGGCTCAG-3') and R1492 (5'-TACGGYTACCTTGTTACGACTT-3') [16]. Reaction 
mixtures $(25 \mathrm{~mL})$ were prepared as follows: $8.75 \mu \mathrm{L}$ of ultrapure water, $5 \mu \mathrm{L}$ of GoTaq ${ }^{\circledR}$ Flexi DNA Polymerase Buffer (Promega, Madison, WI, USA), $3 \mu \mathrm{L}$ of $\mathrm{MgCl}_{2}, 25 \mathrm{mM}, 2.5 \mu \mathrm{L}$ dNTPs, $2 \mathrm{mM}$, $1.5 \mu \mathrm{L}$ of each primer, $10 \mu \mathrm{M}, 1.25$ of dimethyl sulfoxide (DMSO) $100 \%, 0.5 \mu \mathrm{L}$ GoTaq ${ }^{\circledR}$ Flexi DNA Polymerase $5 \mathrm{U} / \mu \mathrm{L}$ and $1 \mu \mathrm{L}$ of DNA template. Thermal cycling started with an initial denaturation step of $94{ }^{\circ} \mathrm{C}$ for $3 \mathrm{~min}, 35$ cycles of $94{ }^{\circ} \mathrm{C}$ for $1 \mathrm{~min}, 55^{\circ} \mathrm{C}$ for $1 \mathrm{~min}, 72{ }^{\circ} \mathrm{C}$ for $72 \mathrm{~min}$ and a final extension step of $72{ }^{\circ} \mathrm{C}$ for $10 \mathrm{~min}$. All PCR amplifications were carried out in a Gradient Thermal cycler (Thermo Fisher Scientific, Waltham, MA, USA). All amplicons were checked under UV light after electrophoresis in $1.5 \%$ agarose gels stained with RedSafe ${ }^{\mathrm{TM}}$ (iNtRON Biotechnology, Seongnam-Si, Korea). PCR products with the right size ( $c$. 1500 bp) were cleaned with DNA Clean \& Concentrator ${ }^{\mathrm{TM}}-5$ (Zymo Research Europe GmbH, Freiburg, Deutschland) columns and subjected to sequencing with the Sanger method in a BigDye Terminator 3 (Applied Biosystems, Foster City, CA, USA) using the forward and reverse primer. Nearly complete 16S rRNA gene sequences were obtained by sequencing with the forward and reverse primers. All sequences were automatically trimmed using the Phred quality score method [42]. Their closest phylogenetic relatives were searched for using the Basic Local Alignment Search Tool (BLAST, National Library of Medicine, Bethesda, MD, USA) of the National Center for Biotechnology Information (NCBI, National Library of Medicine, Bethesda, MD, USA) database.

\subsection{Preparation of Epiphytic Bacteria Extracts}

Isolated bacteria were cultured in $500 \mathrm{~mL}$ of Marine Broth (peptone, $5 \mathrm{~g}$; yeast extract, $1 \mathrm{~g}$; $\mathrm{FePO}_{4}$, $0.1 \mathrm{~g}$; dissolved in $1 \mathrm{~L}$ seawater; $\mathrm{pH} 7.2-7.6$ ) and incubated with aeration for three days at $25{ }^{\circ} \mathrm{C}$. Bacteria cells were centrifuged and the pellet recovered and lyophilized. Lyophilized cells were then extracted with methanol and dichloromethane (1:1) at constant stirring for $12 \mathrm{~h}$. The solvents were evaporated in a rotary evaporator at $40{ }^{\circ} \mathrm{C}$, and the extracts were solubilized in dimethyl sulfoxide (DMSO) and stored at $-20{ }^{\circ} \mathrm{C}$ until further use.

\subsection{Biological Activities}

\subsubsection{Antioxidant Activities}

\subsubsection{Quantification of Total Phenolic Content (TPC)}

The TPC of bacteria extracts was determined using the Folin-Ciocalteu method adapted to the microscale [43]. Briefly, $2 \mu \mathrm{L}$ of sample were added to $158 \mu \mathrm{L}$ of distilled water, $10 \mu \mathrm{L}$ of Folin-Ciocalteu reagent and $30 \mu \mathrm{L}$ of $20 \%$ sodium carbonate. After one hour of reaction in the dark, the absorbance was measured at $755 \mathrm{~nm}$ (Synergy H1 Multi-Mode Microplate Reader, BioTek ${ }^{\circledR}$ Instruments, Winooski, Vermont, USA) and used to calculate the phenolic content using gallic acid as the standard.

\subsubsection{DPPH Radical Scavenging Activity}

The DPPH free radical scavenging method was performed according to Brand-Williams (1995) [44] adapted to the microscale with slight modifications. The DPPH radical was dissolved in methanol 
$(0.1 \mathrm{mM})$. Various concentrations of $2 \mu \mathrm{L}$ of sample solution were added to $198 \mu \mathrm{L}$ of the DPPH radical solution. The mixture was vortexed for $1 \mathrm{~min}$ and allowed to stand at room temperature in the dark for $30 \mathrm{~min}$, at which time, the decrease in absorbance at $517 \mathrm{~nm}$ was measured (Synergy H1 Multi-Mode Microplate Reader, BioTek ${ }^{\circledR}$ Instruments). The radical solution was freshly prepared each day. The synthetic antioxidant, BHT, was used as the standard. The ability to scavenge the DPPH radical was calculated using the follow equation:

$$
\text { Scavenging effect }(\%)=\frac{1-\left(\mathrm{A}_{\text {sample }}-\mathrm{A}_{\text {sample blank }}\right)}{\mathrm{A}_{\text {control }}} \times 100
$$

where $\mathrm{A}_{\text {control }}$ is the absorbance of the control (198 $\mu \mathrm{L}$ of DPPH solution plus $2 \mu \mathrm{L}$ DMSO), $\mathrm{A}_{\text {sample }}$ is the absorbance of the test sample (198 $\mu \mathrm{L}$ of DPPH solution plus $2 \mu \mathrm{L}$ sample) and $\mathrm{A}_{\text {sample blank }}$ is the absorbance of the sample in methanol (198 $\mu \mathrm{L}$ of $\mathrm{MeOH}$ plus $2 \mu \mathrm{L}$ of sample).

\subsubsection{Oxygen Radical Absorbent Capacity (ORAC)}

The oxygen radical absorbance capacity assay (ORAC) method was performed as described by Dávalos and co-workers [45] as follows: the reaction was carried out in $75 \mathrm{mM}$ phosphate buffer $(\mathrm{pH} 7.4)$, and the final reaction mixture was $200 \mu \mathrm{L}$. The sample $(20 \mu \mathrm{L})$ and fluorescein $(120 \mu \mathrm{L}$; $70 \mathrm{nM}$, final concentration) were placed in the well of the microplate. The mixture was pre-incubated for $15 \mathrm{~min}$ at $37^{\circ} \mathrm{C}$. 2,2'-azobis (2-amidinopropane) dihydrochloride (AAPH), a free radical generator, was rapidly added using a multichannel pipet $(60 \mu \mathrm{L} ; 12 \mathrm{mM}$, final concentration). The microplate was immediately placed in the reader and the fluorescence recorded every minute for $240 \mathrm{~min}$. The microplate was automatically shaken prior to each reading. Trolox (6-hydroxy-2,5,7, 8-tetramethylchroman-2-carboxylic acid), which is a hydrophilic analogue of vitamin E, was used to perform eight calibration solutions (1-8 $\mu \mathrm{M}$, final concentration) on each assay together with a blank using phosphate buffer instead of the fluorescein.

Antioxidant curves (fluorescence versus time) were first normalized to the curve of the blank corresponding to the same assay by multiplying original data by the factor

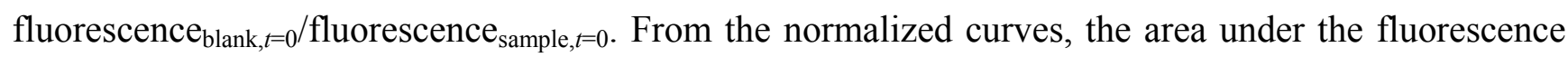
decay curve (AUC) was calculated as:

$$
\mathrm{AUC}=1+i=1 i=240 f_{\mathrm{i}} / f_{0}
$$

where $f_{0}$ is the initial fluorescence reading at $0 \mathrm{~min}$ and $f_{\mathrm{i}}$ is the fluorescence reading at time $i$. The net AUC corresponding to a sample was calculated by subtracting the AUC corresponding to the blank. Regression equations between net $\mathrm{AUC}$ and antioxidant concentration were calculated for all the samples. ORAC values were expressed as micromoles of Trolox equivalent/gram of extract by using the standard curve calculated for each assay.

\subsubsection{Antimicrobial Activity}

The antimicrobial activity of bacteria extracts was evaluated against seven microorganisms: Escherichia coli (ATCC 25922), Pseudomonas aeruginosa (ATCC 27853), Bacillus subtilis (ATCC 6633) and Salmonella enteritidis (ATCC 13076) cultured in Luria broth (LB); Staphylococcus aureus (ATCC 25923) cultured in trypticase soy yeast extract medium (TSYE); and Saccharomyces 
cerevisiae (ATCC 9763) and Candida albicans (ATCC 10231) cultured in yeast extract peptone dextrose (YPD) medium. All mediums were obtained from Merck (Darmstadt, Germany).

Microorganisms growth was monitored spectrophotometrically (optical density at $600 \mathrm{~nm}\left(\mathrm{OD}_{600}\right)$ ) during $48 \mathrm{~h}$ (data not shown) to determine the beginning of the exponential phase, in which the effect of bacterial extracts compared with the vehicle (microorganisms growth in the presence of 1\% DMSO) will be assessed.

The antimicrobial assays were performed in 96-well plates, where $193 \mu \mathrm{L}$ of medium, $5 \mu \mathrm{L}$ of microorganism inoculum and $2 \mu \mathrm{L}$ of extracts samples were added per well. Bacteria were incubated at $37{ }^{\circ} \mathrm{C}$ and fungi at $30^{\circ} \mathrm{C}$. As positive controls, ampicillin $(0.01-1 \mu \mathrm{g} / \mathrm{mL})$, amphotericin b $(1-100 \mu \mathrm{g} / \mathrm{mL})$, bacitracin $(0.1-10 \mu \mathrm{g} / \mathrm{mL})$, chloramphenicol $(1-100 \mu \mathrm{g} / \mathrm{mL})$ and oxytetracycline (0.01-1 $\mu \mathrm{g} / \mathrm{mL}$ ), purchased from Sigma Aldrich (Oakville, Canada), were used, previously prepared in sterile-filtered DMSO and stored at $-20{ }^{\circ} \mathrm{C}$. The ability of bacteria extracts to inhibit the microorganisms growth was accompanied by optical density at $600 \mathrm{~nm}$ (Synergy H1 Multi-Mode Microplate Reader, BioTek ${ }^{\circledR}$ Instruments). Results were expressed in the percentage of control.

\subsection{Statistical Analysis}

Results are presented as the mean \pm standard error of mean (SEM). The $\mathrm{IC}_{50}$ concentration was calculated from nonlinear regression analysis using the GraphPad Prism software with the equation: $\mathrm{Y}=100 /\left(1+10^{\left(\mathrm{X}-\operatorname{LogIC}_{50}\right)}\right)$.

\section{Conclusions}

To the best of our knowledge, for the first time, Bifurcaria bifurcata-associated bacteria were isolated and identified. This study reveals that B. bifurcata epiphytic bacteria are an excellent source of new natural antioxidant compounds, as well as antimicrobial compounds against Gram-positive bacteria. Moreover, all bacteria presented in this work are cultivable in a flask scale, which opens an opportunity for the production of the bioactive compounds in an industrial scale. As the production of secondary metabolites is related to environmental factors, such as UV radiation, $\mathrm{pH}$, temperature, nutrient availability and time of fermentation, these can be manipulated in order to expose the bacteria to stress situations eliciting the production of the target bioactive compound. From a biotechnological perspective, the production of secondary metabolites, as effective competition and defense strategies by surface-associated microorganisms, constitutes an unparalleled reservoir for the discovery of new drugs, therapeutic agents and bioactive molecules, with applications across medical, industrial and environmental settings.

\section{Acknowledgments}

This work was supported through funding provided by the European Commission Collaborative Project FP7 KBBE 2010-4 BAMMBO (project number 265896). 


\section{Author Contributions}

The experimental design was carried out by André Horta, Susete Pinteus, Celso Alves, Américo Rodrigues and Rui Pedrosa. The laboratorial experiments were performed by André Horta, Susete Pinteus, Celso Alves, Nádia Fino, Joana Silva and Sara Fernandez. The manuscript was written by Susete Pinteus, André Horta, Celso Alves and Rui Pedrosa.

\section{Conflicts of Interest}

The authors declare no conflict of interest.

\section{References}

1. Debbab, A.; Aly, A.H.; Lin, W.H.; Proksch, P. Bioactive compounds from marine bacteria and fungi. Microb. Biotechnol. 2010, 3, 544-563.

2. Zheng, L.-H.; Wang, Y.-J.; Sheng, J.; Wang, F.; Zheng, Y.; Lin, X.-K.; Sun, M. Antitumor peptides from marine organisms. Mar. Drugs 2011, 9, 1840-1859.

3. Kim, S.-K. Marine Cosmeceuticals: Trends and Prospects; CRS Press: New York, NY, USA, 2012.

4. Aneiros, A.; Garateix, A. Bioactive peptides from marine sources: Pharmacological properties and isolation procedures. J. Chromatogr. B 2004, 803, 41-53.

5. Kim, S.-K. Marine Pharmacognosy: Trends and Applications; CRS Press: New York, NY, USA, 2013.

6. Kijjoa, A.; Sawangwong, P. Drugs and cosmetics from the sea. Mar. Drugs 2004, 2, 73-82.

7. Graça, A.P.; Bondoso, J.; Gaspar, H.; Xavier, J.R.; Monteiro, M.C.; de la Cruz, M.; Oves-Costales, D.; Vicente, F.; Lage, O.M. Antimicrobial activity of heterotrophic bacterial communities from the marine sponge Erylus discophorus (astrophorida, geodiidae). PLoS One 2013, 8, e78992.

8. Penesyan, A.; Marshall-Jones, Z.; Holmstrom, C.; Kjelleberg, S.; Egan, S. Antimicrobial activity observed among cultured marine epiphytic bacteria reflects their potential as a source of new drugs. FEMS Microbiol. Ecol. 2009, 69, 113-124.

9. Hollants, J.; Leliaert, F.; de Clerck, O.; Willems, A. What we can learn from sushi: A review on seaweed-bacterial associations. FEMS Microbiol. Ecol. 2013, 83, 1-16.

10. Rahman, A. Studies in Natural Products Chemistry, Bioactive Natural Products (Part F); Elsevier Science: Oxford, UK, 2001; Volume 25.

11. Kim, S.-K. Marine Microbiology: Bioactive Compounds and Biotechnological Applications; Wiley-VCH: Weinheim, Germany, 2013.

12. Zheng, L.; Han, X.; Chen, H.; Lin, W.; Yan, X. Marine bacteria associated with marine macroorganisms: The potential antimicrobial resources. Ann. Microbiol. 2005, 55, 119-124.

13. Goecke, F.; Labes, A.; Wiese, J.; Imhoff, J. Dual effects of macroalgal extracts on growth of bacteria in western baltic sea. Rev. Biol. Mar. Oceanogr. 2012, 47, 75-86.

14. Soria-Mercado, I.E.; Villarreal-Gómez, L.J.; Rivas, G.G.; Sánchez, N.E.A. Bioactive Compounds from Bacteria Associated to Marine Algae; InTech: Rijeka, Croatia, 2012. 
15. Penesyan, A.; Tebben, J.; Lee, M.; Thomas, T.; Kjelleberg, S.; Harder, T.; Egan, S. Identification of the antibacterial compound produced by the marine epiphytic bacterium Pseudovibrio sp. D323 and related sponge-associated bacteria. Mar. Drugs 2011, 9, 1391-1402.

16. Weisburg, W.; Barns, S.; Pelletier, D.; Lane, D. 16S Ribosomal DNA Amplification for Phylogenetic Study. J. Bacteriol. 1991, 697-703.

17. Murray, P.M.; Moane, S.; Collins, C.; Beletskaya, T.; Thomas, O.P.; Duarte, A.W.F.; Nobre, F.S.; Owoyemi, I.O.; Pagnocca, F.C.; Sette, L.D.; et al. Sustainable production of biologically active molecules of marine based origin. New Biotechnol. 2013, 30, 839-850.

18. Muñoz, J.; Culioli, G.; Köck, M. Linear diterpenes from the marine brown alga Bifurcaria bifurcata: A chemical perspective. Phytochem. Rev. 2013, 12, 407-424.

19. Spavieri, J.; Allmendinger, A.; Kaiser, M.; Casey, R.; Hingley-Wilson, S.; Lalvani, A.; Guiry, M.D.; Blunden, G.; Tasdemir, D. Antimycobacterial, antiprotozoal and cytotoxic potential of twenty-one brown algae (phaeophyceae) from british and irish waters. Phytother. Res. 2010, $24,1724-1729$.

20. Jiménez-Escrig, A.; Gómez-Ordóñez, E.; Rupérez, P. Brown and red seaweeds as potential sources of antioxidant nutraceuticals. J. Appl. Phycol. 2012, 24, 1123-1132.

21. Ducklow, H. Bacterial Production and Biomass in the Ocean. In Microbial Ecology of the Oceans, 1st ed.; Kirchman, D.L., Ed.; Wiley: New York, NY, USA, 2000; pp. 85-120.

22. Hamid, R.; Usup, G.; Ahmad, A. Antimicrobial activity of bacteria associated with various marine sources. Adv. Environ. Biol. 2013, 7, 356-365.

23. Yang, S.-H.; Kwon, K.K.; Lee, H.-S.; Kim, S.-J. Shewanella spongiae sp. nov., isolated from a marine sponge. Int. J. Syst. Evol. Microbiol. 2006, 56, 2879-2882.

24. Sawabe, T.; Ohtsuka, M.; Ezura, Y. Novel alginate lyases from marine bacterium Alteromonas sp. Strain h-4. Carbohydr. Res. 1997, 304, 69-76.

25. Jafarzade, M.; Mohamad, S.; Usup, G.; Ahmad, A. Heavy-metal tolerance and antibiotic susceptibility of red pigmented bacteria isolated from marine environment. Nat. Resour. 2012, 3, 171-174.

26. Huo, Y.-Y.; Xu, X.-W.; Li, X.; Liu, C.; Cui, H.-L.; Wang, C.-S.; Wu, M. Ruegeria marina sp. nov., isolated from marine sediment. Int. J. Syst. Evol. Microbiol. 2011, 61, 347-350.

27. Gunn, B.; Colwell, R. Numerical taxonomy of Staphylococci isolated from the marine environment. Int. J. Syst. Bacteriol. 1983, 33, 751-759.

28. Kalinovskaya, N.I.; Romanenko, L.A.; Irisawa, T.; Ermakova, S.P.; Kalinovsky, A.I. Marine isolate Citricoccus sp. Kmm 3890 as a source of a cyclic siderophore nocardamine with antitumor activity. Microbiol. Res. 2011, 166, 654-661.

29. Karthik, L.; Kumar, G.; Rao, K.V.B. Antioxidant activity of newly discovered lineage of marine actinobacteria. Asian Pac. J. Trop. Med. 2013, 6, 325-332.

30. Silva, J.; Alves, C.; Pinteus, S.; Horta, A.; Pedrosa, R. High antioxidant activity of Sargassum muticum and Padina pavonica collected from peniche coast (portugal). Curr. Opin. Biotechnol. 2013, 24, S116.

31. Kalirajan, A.; Ranjit Singh, A. Antioxidant potential and biochemical evaluation of metabolites from the marine bacteria Virgibacillus sp. associated with the sponge Callyspongia diffusa. Free Radic. Antioxid. 2013, 3, 47-51. 
32. Kindleysides, S.; Quek, S.-Y.; Miller, M.R. Inhibition of fish oil oxidation and the radical scavenging activity of new zealand seaweed extracts. Food Chem. 2012, 133, 1624-1631.

33. Zulueta, A.; Esteve, M.J.; Frígola, A. Orac and teac assays comparison to measure the antioxidant capacity of food products. Food Chem. 2009, 114, 310-316.

34. Wang, T.; Jonsdottir, R.; Ólafsdóttir, G. Total phenolic compounds, radical scavenging and metal chelation of extracts from icelandic seaweeds. Food Chem. 2009, 116, 240-248.

35. Okuyama, H.; Orikasa, Y.; Nishida, T. Significance of antioxidative functions of eicosapentaenoic and docosahexaenoic acids in marine microorganisms. Appl. Environ. Microbiol. 2008, 74, $570-574$.

36. Barja, J.L.; Lemos, M.L.; Toranzo, A.E. Purification and characterization of an antibacterial substance produced by a marine Alteromonas species. Antimicrob. Agents Chemother. 1989, 33, 1674-1679.

37. Shiozawa, H.; Kagasaki, T.; Kinoshita, T.; Haruyama, H.; Domon, H.; Utsui, Y.; Kodama, K.; Takahashi, S. Thiomarinol, a new hybrid antimicrobial antibiotic produced by a marine bacterium: Fermentation, isolation, structure, and antimicrobial activity. J. Antibiot. 1993, 46, 1834-1842.

38. Abraham, T. Antibacterial marine bacterium deter luminous vibriosis in shrimp larvae. NAGA WorldFish Cent. Quart. 2004, 27, 28-31.

39. Wilson, G.S.; Raftos, D.A.; Nair, S.V. Antimicrobial activity of surface attached marine bacteria in biofilms. Microbiol. Res. 2011, 166, 437-448.

40. Sofidiya, M.O.; Odukoya, O.A.; Afolayan, A.J.; Familoni, O.B. Phenolic contents, antioxidant and antibacterial activities of Hymenocardia acida. Nat. Prod. Res. 2009, 23, 168-177.

41. Kanagasabhapathy, M.; Sasaki, H.; Haldar, S.; Yamasaki, S.; Nagata, S. Antibacterial activities of marine epibiotic bacteria isolated from brown algae of japan. Ann. Microbiol. 2006, 56, 167-173.

42. Sørensen, E.; Rasmussen, E.M.; Eriksen, B.; Larsen, H.J.; Morling, N. Evaluation and validation of quality assessment of mitochondrial control region sequence data by phred. Int. Congr. Ser. 2004, 1261, 94-96.

43. Singleton, V.L.; Rossi, J.A. Colorimetry of total phenolics with phosphomolybdic-phosphotungstic acid reagents. Am. J. Enol. Vitic. 1965, 16, 144-158.

44. Brand-Williams, W.; Cuvelier, M.E.; Berset, C. Use of a free radical method to evaluate antioxidant activity. LWT Food Sci. Technol. 1995, 28, 25-30.

45. Dávalos, A.; Gómez-Cordovés, C.; Bartolomé, B. Extending applicability of the oxygen radical absorbance capacity (ORAC-fluorescein) assay. J. Agric. Food Chem. 2003, 52, 48-54.

(C) 2014 by the authors; licensee MDPI, Basel, Switzerland. This article is an open access article distributed under the terms and conditions of the Creative Commons Attribution license (http://creativecommons.org/licenses/by/3.0/). 